influences and tendencies in public affairs in early Iowa shall ever be able to exhaust a study embracing the early newspaper phase of the beginnings of Iowa, without having resorted with profit to Mr. Mott's present work.

Thus a beginning has been made toward readier presentation of the scope and contents of one of the very valuable collections of Iowa and Western source materials. Hitherto it has called for more exahusting time and labor of those who have made use of it than will be now required. When similar work shall have been done upon the papers founded in Iowa during and after the Civil War, a fair sailing chart through the newspaper sea of Iowa materials will exist. Then there remains to be prepared the second or index phase of the work, and this we have begun.

\title{
THE SINCLAIRS OF OLD FORT DES MOINES
}

Hon. Johnson Brigham, State Librarian, has recently published his romance of the above title. Of the numerous complimentary . letters concerning his book Mr. Brigham has permitted us to publish the following:

Thanksgiving Day.

24th November, 1927.

My dear old friend Johnson Brigham:

You have given me and Miss Thompson, a great pleasure with your charming story of Old Fort Des Moines. We read every word of it aloud. Any one interested in dear old Iowa should like to read this romance of the state's beginnings.

It is a simple story simply told and well told. It takes me back to the days too, when, as a boy, I knew and loved the Des Moines river. Once I tramped six miles, bare-footed, just to see one of the early steamboats pass up the river to Des Moines; yes, that was long ago, for that bare-foot boy is in his ninetieth year now. I recall too, how that one of the very first little poems. I ever wrote was about the Des Moines river. It was great to me then and nothing brings it back to me so vividly now as the pages of your little book. The other night when Miss $T$. was reading one of its little touching and simple episodes I turned my face away to hide some tears that came in spite of me. I know of no better praise of a book than that. . .

Yours,

S. H. M. BYERS, Los Angeles, Calif. 
Copyright of Annals of Iowa is the property of State of Iowa, by \& through the State Historical Society of Iowa and its content may not be copied or emailed to multiple sites or posted to a listserv without the copyright holder's express written permission. However, users may print, download, or email articles for individual use. 